NASA/TM-2003-212511

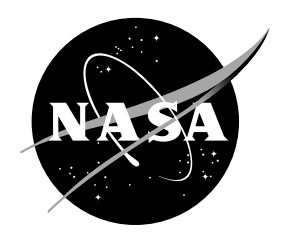

\title{
Silicon Carbide Diodes Performance Characterization and Comparison With Silicon Devices
}

Ramon C. Lebron-Velilla and Gene E. Schwarze

Glenn Research Center, Cleveland, Ohio

Scott Trapp

University of Toledo, Toledo, Ohio 
Since its founding, NASA has been dedicated to the advancement of aeronautics and space science. The NASA Scientific and Technical Information (STI) Program Office plays a key part in helping NASA maintain this important role.

The NASA STI Program Office is operated by Langley Research Center, the Lead Center for NASA's scientific and technical information. The NASA STI Program Office provides access to the NASA STI Database, the largest collection of aeronautical and space science STI in the world. The Program Office is also NASA's institutional mechanism for disseminating the results of its research and development activities. These results are published by NASA in the NASA STI Report Series, which includes the following report types:

- $\quad$ TECHNICAL PUBLICATION. Reports of completed research or a major significant phase of research that present the results of NASA programs and include extensive data or theoretical analysis. Includes compilations of significant scientific and technical data and information deemed to be of continuing reference value. NASA's counterpart of peerreviewed formal professional papers but has less stringent limitations on manuscript length and extent of graphic presentations.

- TECHNICAL MEMORANDUM. Scientific and technical findings that are preliminary or of specialized interest, e.g., quick release reports, working papers, and bibliographies that contain minimal annotation. Does not contain extensive analysis.

- CONTRACTOR REPORT. Scientific and technical findings by NASA-sponsored contractors and grantees.
- CONFERENCE PUBLICATION. Collected papers from scientific and technical conferences, symposia, seminars, or other meetings sponsored or cosponsored by NASA.

- SPECIAL PUBLICATION. Scientific, technical, or historical information from NASA programs, projects, and missions, often concerned with subjects having substantial public interest.

- TECHNICAL TRANSLATION. Englishlanguage translations of foreign scientific and technical material pertinent to NASA's mission.

Specialized services that complement the STI Program Office's diverse offerings include creating custom thesauri, building customized databases, organizing and publishing research results ... even providing videos.

For more information about the NASA STI Program Office, see the following:

- Access the NASA STI Program Home Page at http://www.sti.nasa.gov

- E-mail your question via the Internet to help@sti.nasa.gov

- Fax your question to the NASA Access Help Desk at 301-621-0134

- Telephone the NASA Access Help Desk at 301-621-0390

- Write to:

NASA Access Help Desk

NASA Center for AeroSpace Information 7121 Standard Drive

Hanover, MD 21076 
NASA/TM-2003-212511

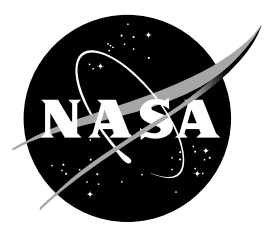

\section{Silicon Carbide Diodes Performance Characterization and Comparison With Silicon Devices}

Ramon C. Lebron-Velilla and Gene E. Schwarze

Glenn Research Center, Cleveland, Ohio

Scott Trapp

University of Toledo, Toledo, Ohio

Prepared for the

First International Energy Conversion Engineering Conference cosponsored by the American Institute of Aeronautics and Astronautics (AIAA), the American Society of Mechanical Engineers (ASME), and the Institute of Electrical and Electronics (IEEE)

Portsmouth, Virginia, August 17-21, 2003

National Aeronautics and

Space Administration

Glenn Research Center 
Trade names or manufacturers' names are used in this report for identification only. This usage does not constitute an official endorsement, either expressed or implied, by the National Aeronautics and Space Administration.

Available from

NASA Center for Aerospace Information 7121 Standard Drive

Hanover, MD 21076
National Technical Information Service 5285 Port Royal Road Springfield, VA 22100

Available electronically at http:/ /gltrs.grc.nasa.gov 


\section{SILICON CARBIDE DIODES PERFORMANCE CHARACTERIZATION AND COMPARISON WITH SILICON DEVICES}

\author{
Ramon C. Lebron-Velilla and Gene E. Schwarze \\ National Aeronautics and Space Administration \\ Glenn Research Center \\ Cleveland, Ohio 44135
}

\author{
Scott Trapp \\ University of Toledo \\ Toledo, Ohio 43606
}

\begin{abstract}
$\underline{\text { ABSTRACT }}$
Commercially available silicon carbide (SiC) Schottky diodes from different manufacturers were electrically tested and characterized at room temperature. Performed electrical tests include steady state forward and reverse I-V curves, as well as switching transient tests performed with the diodes operating in a hard switch dc to dc "buck" converter. The same tests were performed in current state of the art silicon ( $\mathrm{Si}$ ) and gallium arsenide (GaAs) Schottky and pn junction devices for evaluation and comparison purposes. The SiC devices tested have a voltage rating of 200, 300, and $600 \mathrm{~V}$. The comparison parameters are forward voltage drop at rated current, reverse current at rated voltage and peak reverse recovery currents in the dc to dc converter. Test results show that steady state characteristics of the tested $\mathrm{SiC}$ devices are not superior to the best available Si Schottky and ultra fast pn junction devices. Transient tests reveal that the tested SiC Schottky devices exhibit superior transient behavior. This is more evident at the 300 and $600 \mathrm{~V}$ rating where $\mathrm{SiC}$ Schottky devices showed drastically lower reverse recovery currents than $\mathrm{Si}$ ultra fast pn diodes of similar rating.
\end{abstract}

\section{INTRODUCTION}

Silicon Carbide ( $\mathrm{SiC}$ ) is a semiconductor material with great potential to impact power electronics applications. Some of the advantages of $\mathrm{SiC}$ over other semiconductor materials include a thermal conductivity that is over three times the thermal conductivity of Silicon, an ability to operate at higher temperatures, and an electrical breakdown field that is ten times higher than silicon or gallium arsenide. Furthermore, $\mathrm{SiC}$ is a wide energy bandgap semiconductor. These materials are better suited for higher frequency operation and are also more resistant to radiation effects [1].

NASA Glenn Research center's Electrical Systems Development Branch is working to demonstrate and test the advantages of $\mathrm{SiC}$ in actual power electronics applications. The first step in this pursuit was to obtain commercially available $\mathrm{SiC}$ Schottky diodes and to individually test them to compare them with current state of the art silicon Schottky and ultra fast $p-n$ diodes of similar voltage and current ratings. This report presents the results of steady state and transient tests performed at NASA Glenn. Forward and reverse current-volt (I-V) plots were generated to compare performance and to measure the forward voltage drop at rated current and the reverse leakage current at rated voltage. In addition, the devices were individually connected as rectifiers in a Buck (step down) dc to dc converter to test their reverse recovery characteristics and compare their transient performance in a typical converter application.

\section{PN DIODES BACKGROUND INFORMATION}

The pn diode is formed when a semiconductor material is doped with donor ions in one side and with acceptor ions on the other [2]. These ions provide electrons in one side ( $n$ type) and holes in the other ( $p$ type). The interface between the two sides is known as the junction and in this region the electrons recombine with holes that move from the $\mathrm{p}$ side by diffusion. Also in this region, the holes recombine with electrons that move from the $\mathrm{n}$ side. This small recombination region is called the depletion region because it has no mobile charges. The ions in this depletion region create an electrostatic potential variation that creates a potential energy barrier that prevents the further flow of holes into the $\mathrm{n}$ side and the further flow of electrons into the $\mathrm{p}$ side. The $\mathrm{p}$ side corresponds to the anode and the $\mathrm{n}$ side is the cathode.

A positive voltage applied from anode to cathode will allow holes to move into the $\mathrm{n}$ side and electrons to move into the $\mathrm{p}$ side. The total forward bias current is the combination of both holes and electrons currents (combination of both majority and minority carriers). Electrons in the $\mathrm{p}$ region and holes in the $\mathrm{n}$ regions are called minority carriers. When a negative voltage is applied from anode to cathode (reverse bias), the holes in the $\mathrm{p}$ region and electrons in the $\mathrm{n}$ region will move 
away from the junction, preventing the flow of current. In steady state, only a small reverse saturation current will flow due to the presence of a small number of minority carriers that will flow across the junction with the reverse voltage.

When a pn diode is forward biased and carrying forward current, if the bias voltage is reversed abruptly, such as the voltage transitions in switching dc-to-dc converters, the diode will exhibit a transient behavior. Since the diode is carrying full forward current when forward biased, at the time of voltage reversal, there are a large number of minority carriers that will flow across the junction in the reverse direction. This is called reverse recovery current. During this reverse recovery time, the reverse current will be limited only by the external resistance of the circuit. When most of the minority carriers have been removed the diode can then block the full reverse voltage and the reverse current will decrease to the small reverse saturation value.

\section{SCHOTTKY DIODES BACKGROUND INFORMATION}

Schottky diodes are similar to pn diodes but instead of having a junction between an $n$ material and a $\mathrm{p}$ material the junction occurs at the interface between a lightly doped $\mathrm{n}$ type semiconductor and a metal [2]. The difference in the carrier concentration of the two materials creates the potential barrier in the junction. Because both the semiconductor and the metal are $n$ type, the current conduction involves only majority carriers (electrons) without carrier injection, storage or recombination. This is because the electrons from the $n$ type semiconductor enter the metal side, where there are plenty of electrons, and they become part of the metal, therefore there is no storage of charge in the junction. Since there is no minority carrier conduction in a Schottky diode, it does not have a reverse recovery characteristic. That is, the storage time is almost zero and the reverse recovery time involves only the transition time because the recovery time depends only on their parasitic capacitance and not on the recombination of minority carriers. This makes the Schottky diodes perfectly suited for high frequency switching applications. Their reverse recovery behavior can also eliminate the need for snubbers, an attractive feature for low parasitic switching losses.

The steady state forward and reverse voltage and current characteristics (IV curves) of the Schottky are similar to those of the pn diode. But the forward voltage at which the Schottky starts to conduct (cut-in voltage) is lower than the one for the pn diode (approximately $0.3 \mathrm{~V}$ for the Schottky versus $0.7 \mathrm{~V}$ for the PN). Another difference is that the reverse saturation current for the
Schottky is larger than the reverse saturation current for the pn diode. These two differences are due to the large number of electrons in the metal. With more carriers conduction can start at lower forward voltages and also with more carriers available the reverse current becomes larger.

In general, to eliminate this Schottky barrier when a metal lead is connected to a semiconductor, a region of heavily doped silicon (n type) is inserted between the metal lead and the lightly doped semiconductor. This reduces the difference in carrier concentrations between the metal and the semiconductor. This metalsemiconductor contact is known as an ohmic contact.

\section{SIC POTENTIAL BENEFITS}

Current applications of available silicon and gallium arsenide Schottky diodes are limited to reverse blocking voltages of $250 \mathrm{Vdc}$. This is due to Schottky diodes higher reverse leakage current when compared with pn diodes. Also, silicon Schottky rectifiers have a maximum rated junction temperature in the range of 125 to $175^{\circ} \mathrm{C}$, while the pn diodes typical maximum temperature is $200{ }^{\circ} \mathrm{C}$ [3]. This makes the Schottky diode reverse leakage current even higher at higher temperatures, to the point where the reverse losses can be as large as the forward losses.

$\mathrm{SiC}$ allows the production of Schottky diodes rated at 300 and $600 \mathrm{~V}$ mainly because low leakage currents are possible because the metal semiconductor barrier is two times higher than silicon, and also because the higher temperatures do not cause the SiC leakage current to increase at a steep rate. Another important benefit of $\mathrm{SiC}$ is its high thermal conductivity which allows higher current densities, smaller die sizes, smaller packages, and smaller heat sink requirements. This thermal conductivity is comparable with the thermal conductivity of copper [4]. In addition, SiC behavior at higher frequencies allows the use of higher switching frequencies which further reduces the size of filter passive components such as inductors and capacitors. All of these potential benefits are directly related to NASA's goal of reducing the size and weight, as well as, increasing the power density and reliability of power distribution systems. However, $\mathrm{SiC}$ power switches such as MOSFETs or SITs (Static Induction Transistors or vertical channel JFETS) are not yet commercially available due mainly to a wide range of defects in $\mathrm{SiC}$ crystals such as micropipes and screw dislocations [5]. Therefore, more research and development is needed before power electronics applications can exploit the full potential of the material. 


\section{TEST RESULTS}

\section{STEADY STATE TEST RESULTS}

Forward and reverse current-voltage (IV) curves were generated using the Tektronix $370 \mathrm{~A}$ and a $371 \mathrm{~A}$ programmable curve tracer. All tests were conducted at room temperature. The SiC Schottky diodes used for these tests are typical of what is commercially available at the present time. Table 1 contains the $\mathrm{SiC}$ diodes tested. Several devices were tested for each part number, depending on availability. For example, for the UPSC200, 42 devices were tested. For the UPSC603, 4 devices were tested, and for both parts from Infineon 10 devices were tested.

\begin{tabular}{|c|c|c|c|}
\hline Vendor & Part \# & Voltage & Current \\
\hline Microsemi & UPSC200 & $200 \mathrm{~V}$ & $1 \mathrm{~A}$ \\
Microsemi & UPSC603 & $600 \mathrm{~V}$ & $4 \mathrm{~A}$ \\
Infineon & SDT10S30 & $300 \mathrm{~V}$ & $10 \mathrm{~A}$ \\
Infineon & SDT06S60 & $600 \mathrm{~V}$ & $6 \mathrm{~A}$ \\
\hline
\end{tabular}

Table1. Commercially available SiC Schottky diodes Tested

Current state of the art silicon Schottky and ultra fast p$\mathrm{n}$ diodes of similar voltage and current ratings were also tested to compare performance between the new SiC Schottky diodes and the best available silicon devices in the market. Tables 2 thru Table 5 offer the comparison information on forward voltage drop at rated current and reverse current at rated reverse voltage. This information is important because of the difference in current and voltage rating among all the tested devices.

Figure 1 and Figure 3 show the Forward I-V (FIV) curves of the diodes with voltage ratings between 100-200 V and current ratings between 1 and 35 Amps. The curves show that the lowest forward drop at rated current was obtained for the Fairchild SB5100 100 V, $5 \mathrm{~A}$ silicon Schottky with a $0.67 \mathrm{Vdc}$ drop at 5 amps. As expected, the lower voltage Schottky devices exhibit a lower forward voltage drop. At the $150 \mathrm{~V}$ rating level the best forward drop performer was the International Rectifier 150V, 5 A (IR) silicon Schottky 10CTQ150 with a forward drop of $0.73 \mathrm{~V}$ at $5 \mathrm{~A}$. At the $200 \mathrm{~V}$ level the Microsemi ultra fast pn diode UF4003 rated at $200 \mathrm{~V}$ 1A displayed a forward drop of $0.85 \mathrm{~V}$ at $1 \mathrm{~A}$. Both Figure1 and Figure 3 show that the $\mathrm{SiC} 200 \mathrm{~V}, 1 \mathrm{~A}$ Schottky from Microsemi UPSC 200 has the largest forward voltage drop of the two groups with $1.44 \mathrm{~V}$ at 1 Amp.

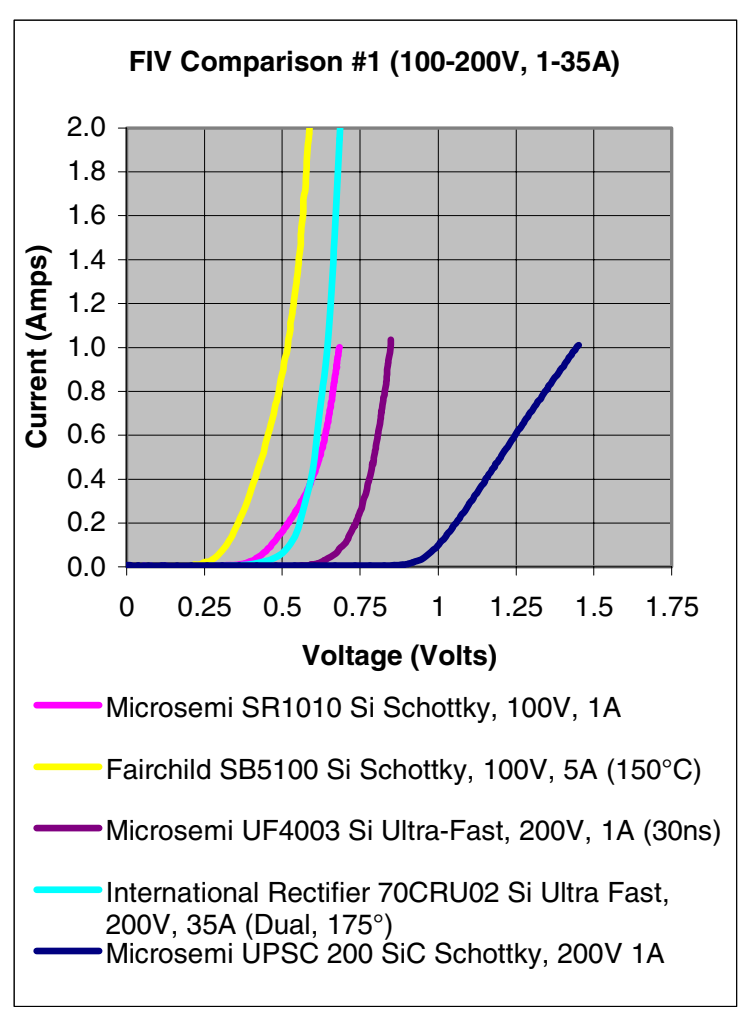

Figure 1. Forward Characteristics Comparison of Diodes rated $100-200 \mathrm{~V}$ and 1-35A

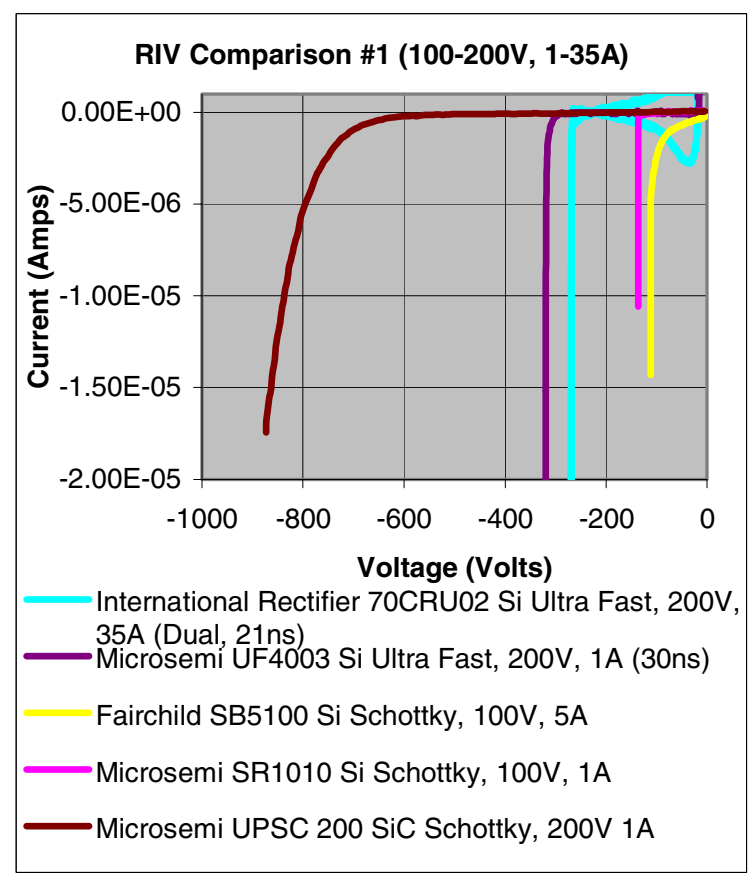

Figure 2. Reverse Characteristics Comparison of Diodes rated $100-200 \mathrm{~V}$ and 1-35A 


\begin{tabular}{|l|l|l|c|c|c|c|c|}
\hline \multicolumn{1}{|c|}{ Type } & Material & Vendor & Part \# & Voltage & Current & Forward V at Rated I & Reverse I at rated V \\
\hline Schottky & $\mathrm{SiC}$ & Microsemi & UPSC200 & $200 \mathrm{~V}$ & $1 \mathrm{~A}$ & $1.44 \mathrm{~V} @ 1 \mathrm{~A}$ & $0.12 \mu \mathrm{A} @ 200 \mathrm{~V}$ \\
Schottky & $\mathrm{Si}$ & Fairchild & SB5100 & $100 \mathrm{~V}$ & $5 \mathrm{~A}$ & $0.67 \mathrm{~V} @ 5 \mathrm{~A}$ & $1.5 \mu \mathrm{A} @ 100 \mathrm{~V}$ \\
Schottky & $\mathrm{Si}$ & Microsemi & SR1010 & $100 \mathrm{~V}$ & $1 \mathrm{~A}$ & $0.68 \mathrm{~V} @ 1 \mathrm{~A}$ & $0.04 \mu \mathrm{A} @ 100 \mathrm{~V}$ \\
p-n & $\mathrm{Si}$ & Microsemi & UF4003 & $200 \mathrm{~V}$ & $1 \mathrm{~A}$ & $0.85 \mathrm{~V} @ 1 \mathrm{~A}$ & $0.1 \mu \mathrm{A} @ 200 \mathrm{~V}$ \\
p-n & $\mathrm{Si}$ & IR & 70CRU02 & 200V & $35 \mathrm{~A}$ & $1.02 \mathrm{~V} @ 35 \mathrm{~A}$ & $0.2 \mu \mathrm{A} @ 200 \mathrm{~V}$ \\
\hline
\end{tabular}

Table 2. Steady State Comparison of Diodes rated 100-200V and 1-35A

Figures 2 and Figure 4 show the Reverse IV (RIV) curves for the above group of diodes. These curves show that most of the diodes in this group have reverse leakage currents that are lower than 2 microamps at reverse voltages lower than their rating, and then the reverse current increases drastically at voltages higher than the rated voltage. An interesting fact from these curves is that the Microsemi SiC 200 V, 1A Schottky diode appears to have an actual voltage rating of $600 \mathrm{~V}$ instead of the specified $200 \mathrm{~V}$. This can help explain the fact that this device has the largest forward drop of the two groups with rating 100 to $200 \mathrm{~V}$. In general, the higher the voltage rating of a device, the higher will be the forward voltage drop that the device will exhibit.

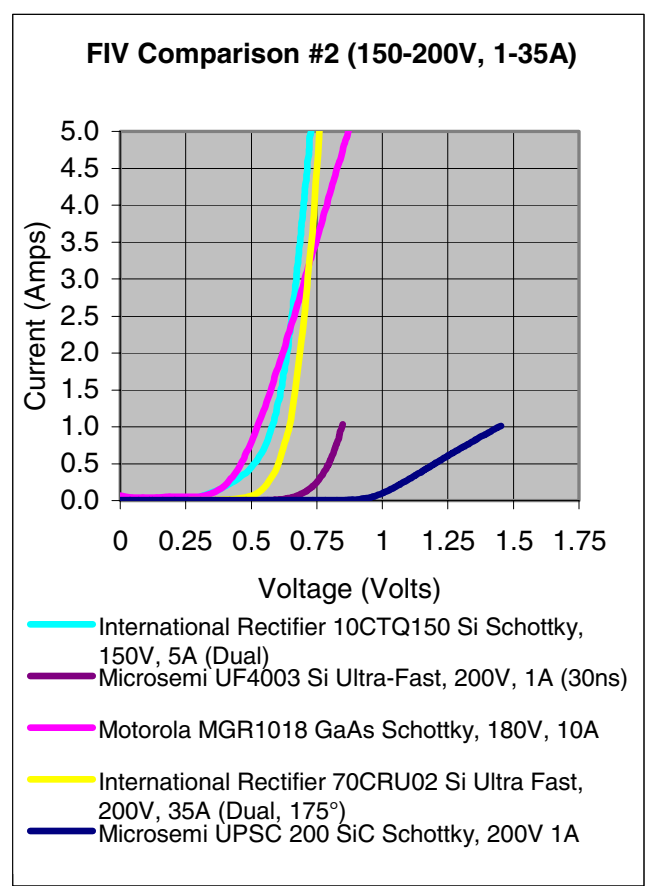

Figure 3. Forward Characteristics Comparison of Diodes rated 150- $200 \mathrm{~V}$ and 1 -35A

Figure 5 contains the forward IV curves of the diodes with voltage ratings of $30 \mathrm{~V}$ and current ratings of $10 \mathrm{~A}$. In this group the IXYS DSEP 803A silicon pn fast recovery diode exhibits a forward voltage drop of $1.33 \mathrm{~V}$ at 10 Amps while the Infineon SDT10S30 SiC Schottky has a higher forward voltage drop with $1.46 \mathrm{~V}$ at 10 amps. On the other side, Figure 6 displays the reverse I-V characteristics for both of these devices. The IXYS device has a reverse leakage current that is smaller than 2 microamps up to a reverse voltage higher than $400 \mathrm{~V}$. The Infineon $\mathrm{SiC}$ device shows a reverse current of approximately 4.8 microamps at rated $300 \mathrm{~V}$. The tested steady performance of the silicon pn device was superior to the performance of the $\mathrm{SiC}$ device in both forward and reverse direction.

Figure 7 shows the forward I-V curves of the devices with voltage rating of $600 \mathrm{~V}$ and current ratings between 4 and 9 Amps. The curves show that the lowest forward drop at rated current was obtained for the Microsemi 1N6628 $600 \mathrm{~V}$, 4A silicon ultra fast pn diode with a $1.02 \mathrm{Vdc}$ drop at 4 amps. A similar performance was obtained for the IXYS DSEI8-06A silicon ultra fast $600 \mathrm{~V}, 8 \mathrm{~A}$ pn with a forward voltage drop of $1.16 \mathrm{~V}$ at 8 amps. The next device in forward performance was the Infineon SDT06S60 a SiC Schottky rated at $600 \mathrm{~V}$ 6A. The forward drop if this device was $1.48 \mathrm{~V}$ at 6 amps.

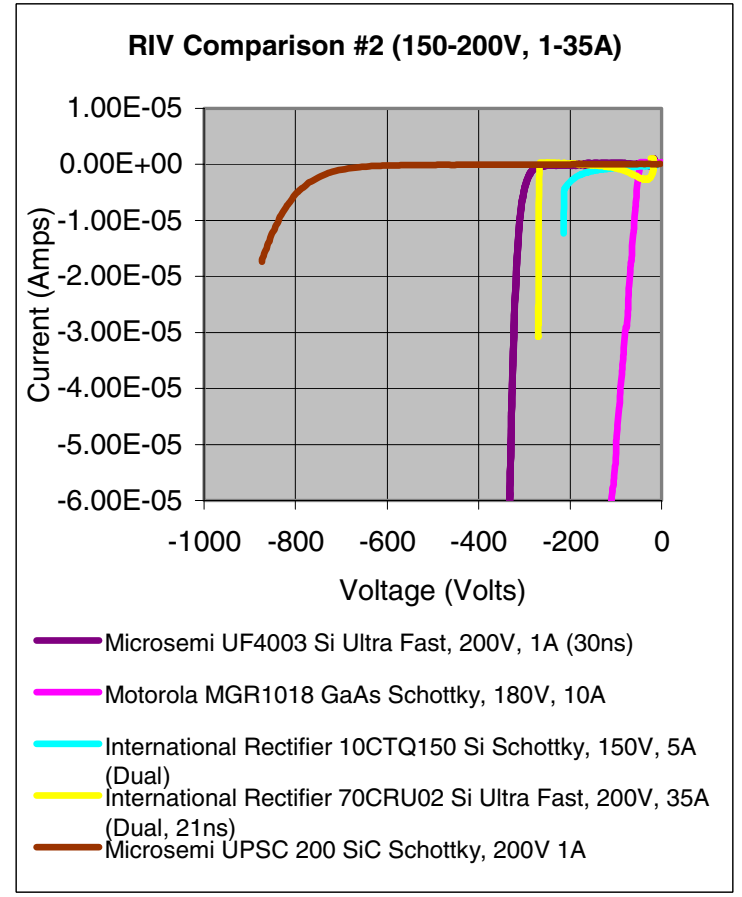

Figure 4. Reverse Characteristics Comparison of Diodes rated 150-200 V and 1 -35A 


\begin{tabular}{|l|l|l|c|cc|c|c|}
\hline Type & Material & Vendor & Part \# & Voltage & Current & Forward V at Rated I & Reverse I at rated V \\
\hline Schottky & $\mathrm{SiC}$ & Microsemi & UPSC200 & $200 \mathrm{~V}$ & $1 \mathrm{~A}$ & $1.44 \mathrm{~V} @ 1 \mathrm{~A}$ & $0.12 \mu \mathrm{A} @ 200 \mathrm{~V}$ \\
Schottky & $\mathrm{GaAs}$ & Motorola & MGR1018 & $180 \mathrm{~V}$ & $10 \mathrm{~A}$ & $1.29 \mathrm{~V} @ 10 \mathrm{~A}$ & $130 \mu \mathrm{A} @ 180 \mathrm{~V}$ \\
Schottky & $\mathrm{Si}$ & $\mathrm{IR}$ & 10CTQ150 & $150 \mathrm{~V}$ & $5 \mathrm{~A}$ & $0.73 \mathrm{~V} @ 5 \mathrm{~A}$ & $1.2 \mu \mathrm{A} @ 150 \mathrm{~V}$ \\
$\mathrm{p}-\mathrm{n}$ & $\mathrm{Si}$ & Microsemi & UF4003 & $200 \mathrm{~V}$ & $1 \mathrm{~A}$ & $0.85 \mathrm{~V} @ 1 \mathrm{~A}$ & $0.1 \mu \mathrm{A} @ 200 \mathrm{~V}$ \\
$\mathrm{p}-\mathrm{n}$ & $\mathrm{Si}$ & $\mathrm{IR}$ & 70CRU02 & 200V & $35 \mathrm{~A}$ & $1.02 \mathrm{~V} @ 35 \mathrm{~A}$ & $0.2 \mu \mathrm{A} @ 200 \mathrm{~V}$ \\
\hline
\end{tabular}

Table 3.Steady State Comparison of Diodes rated 150-200V and 1-35A

\begin{tabular}{|l|l|l|c|c|c|c|c|}
\hline \multicolumn{1}{|c|}{ Type } & Material & Vendor & Part \# & Voltage & Current & Forward V at Rated I & Reverse I at rated V \\
\hline Schottky & $\mathrm{SiC}$ & Infineon & SDT10S30 & $300 \mathrm{~V}$ & $10 \mathrm{~A}$ & $1.46 \mathrm{~V} @ 10 \mathrm{~A}$ & $4.8 \mu \mathrm{A} @ 300 \mathrm{~V}$ \\
$\mathrm{p}-\mathrm{n}$ & $\mathrm{Si}$ & IXYS & DSEP8-03A & $300 \mathrm{~V}$ & $10 \mathrm{~A}$ & $1.33 \mathrm{~V} @ 10 \mathrm{~A}$ & $1.0 \mu \mathrm{A} @ 300 \mathrm{~V}$ \\
\hline
\end{tabular}

Table 4.Steady State Comparison of Diodes rated 300V and 10A

\begin{tabular}{|l|l|l|c|c|c|c|c|}
\hline \multicolumn{1}{|c|}{ Type } & Material & Vendor & Part \# & Voltage & Current & Forward V at Rated I & Reverse I at rated V \\
\hline Schottky & $\mathrm{SiC}$ & Infineon & SDT06S60 & $600 \mathrm{~V}$ & $6 \mathrm{~A}$ & $1.48 \mathrm{~V} @ 6 \mathrm{~A}$ & $47 \mu \mathrm{A} @ 600 \mathrm{~V}$ \\
Schottky & $\mathrm{SiC}$ & Microsemi & UPSC603 & $600 \mathrm{~V}$ & $4 \mathrm{~A}$ & $1.94 \mathrm{~V} @ 4 \mathrm{~A}$ & $6 \mu \mathrm{A} @ 600 \mathrm{~V}$ \\
$\mathrm{p}-\mathrm{n}$ & $\mathrm{Si}$ & Microsemi & 1N6628 & $600 \mathrm{~V}$ & $4 \mathrm{~A}$ & $1.02 \mathrm{~V} @ 4 \mathrm{~A}$ & $0.08 \mu \mathrm{A} @ 600 \mathrm{~V}$ \\
$\mathrm{p}-\mathrm{n}$ & $\mathrm{Si}$ & IXYS & DSEP9-06CR & $600 \mathrm{~V}$ & $9 \mathrm{~A}$ & $3.23 \mathrm{~V} @ 9 \mathrm{~A}$ & $0.3 \mu \mathrm{A} @ 600 \mathrm{~V}$ \\
$\mathrm{p}-\mathrm{n}$ & $\mathrm{Si}$ & IXYS & DSEI8-06A & $600 \mathrm{~V}$ & $8 \mathrm{~A}$ & $1.16 \mathrm{~V} @ 8 \mathrm{~A}$ & $2.2 \mu \mathrm{A} @ 600 \mathrm{~V}$ \\
$\mathrm{p}-\mathrm{n}$ & $\mathrm{Si}$ & $\mathrm{IR}$ & HFA08TB60 & $600 \mathrm{~V}$ & $8 \mathrm{~A}$ & $1.57 \mathrm{~V} @ 8 \mathrm{~A}$ & $0.2 \mu \mathrm{A} @ 600 \mathrm{~V}$ \\
\hline
\end{tabular}

Table 5. Steady State Comparison of Diodes rated 600V and 4-9A

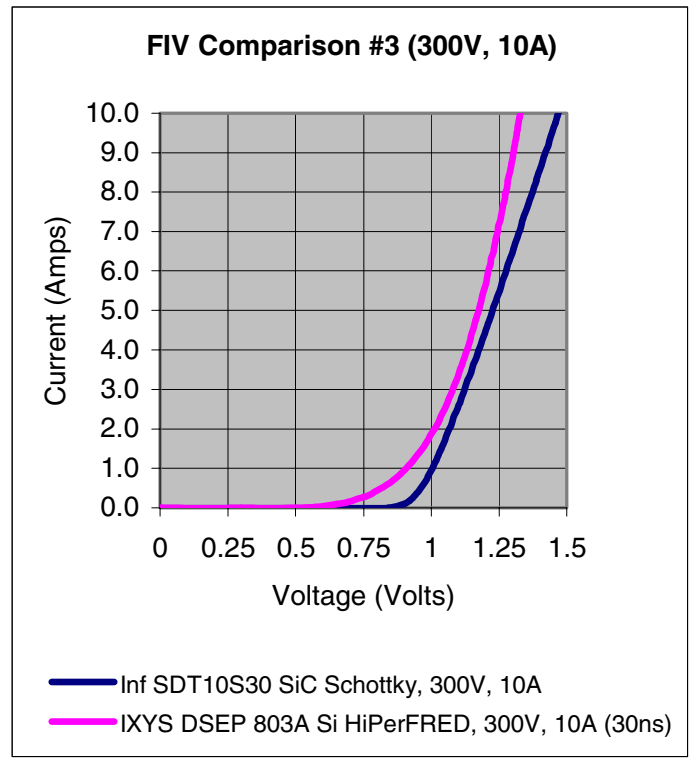

Figure 5. Forward Characteristics Comparison of Diodes rated $300 \mathrm{~V}$ and $10 \mathrm{~A}$

In Figure 7 the Microsemi UPSC $603 \mathrm{SiC} 600 \mathrm{~V}, 4 \mathrm{~A}$ Schottky showed a forward voltage drop of $1.94 \mathrm{Vdc}$ at its rated current of $4 \mathrm{~A}$. This is the largest forward voltage drop for the $600 \mathrm{~V}$ group with the exception of the IXYS DSEP9-06CR a $600 \mathrm{~V}$, 9A a silicon ultra fast pn diode. This device has the fastest reverse recovery time of the $600 \mathrm{~V}$ diodes available in the market today (15 nanoseconds). This diode also has the highest forward voltage drop in the $600 \mathrm{~V}$ group with $3.23 \mathrm{~V}$ at 9 amps.

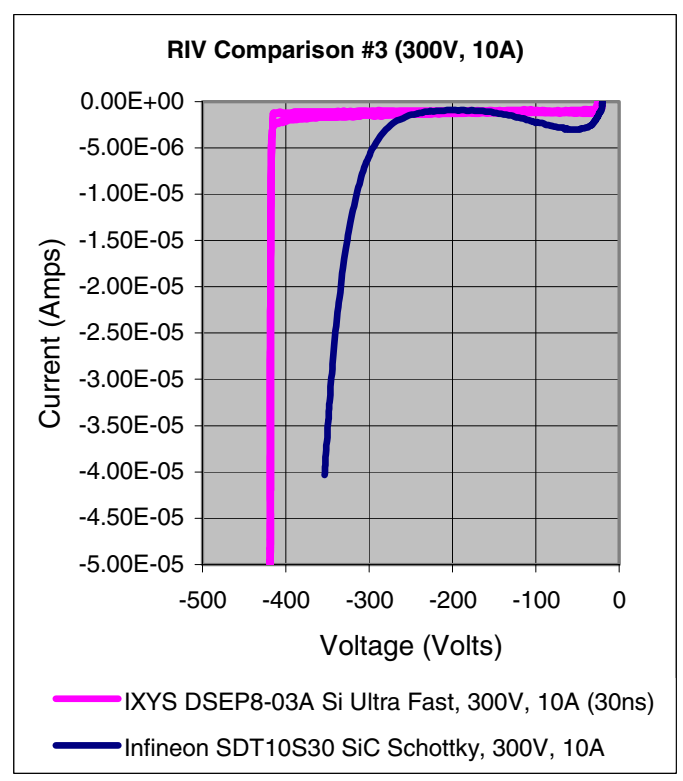

Figure 6. Reverse Characteristics Comparison of Diodes rated $300 \mathrm{~V}$ and $10 \mathrm{~A}$

Figure 8 contains the reverse I-V curves for the $600 \mathrm{~V}$ devices tested. In general, all of the silicon pn devices have leakage currents that are smaller than 2 microamps at reverse voltages lower than $600 \mathrm{~V}$. At reverse voltages higher than $600 \mathrm{~V}$, the leakage currents 


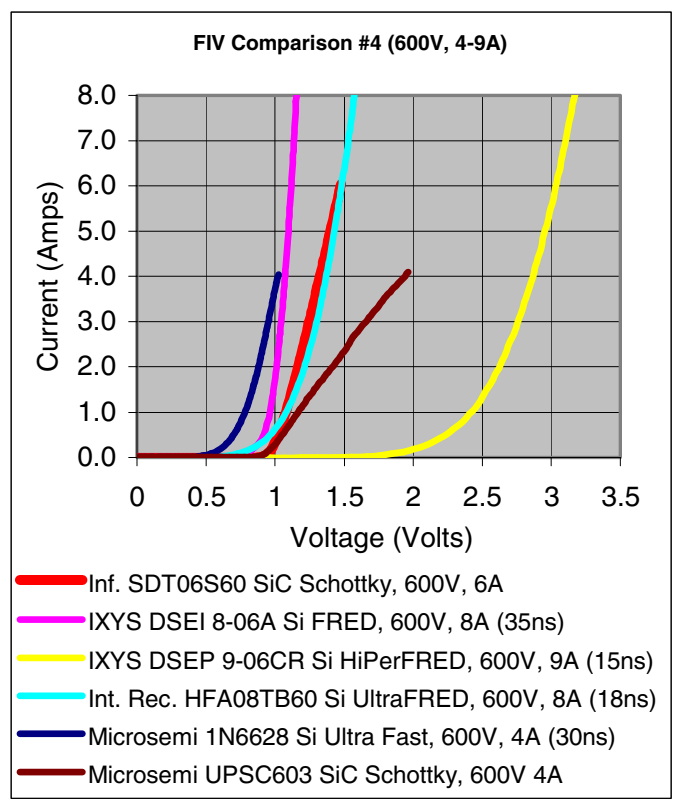

Figure 7. Forward Characteristics Comparison of Diodes rated $600 \mathrm{~V}$ and 4 -9A

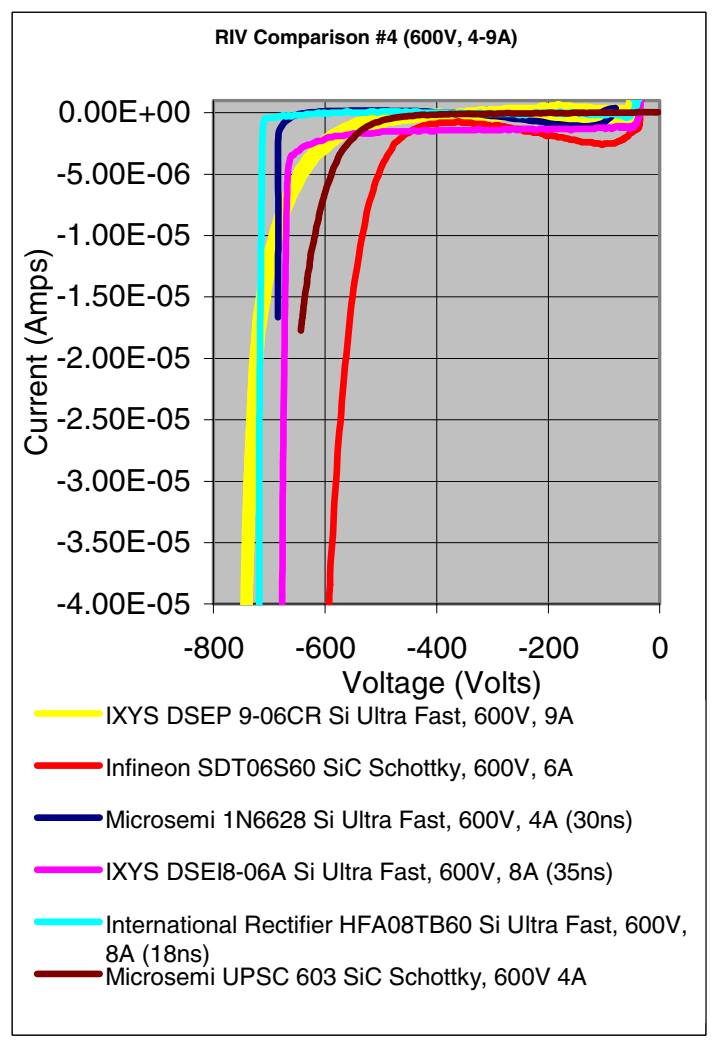

Figure 8. Reverse Characteristics Comparison of Diodes rated $600 \mathrm{~V}$ and $4-9 \mathrm{~A}$ then increase at a steep rate. The Microsemi $\mathrm{SiC}$ UPSC603 (600 V, 4A, Schottky) exhibited a leakage current of 6 microamps at $600 \mathrm{~V}$. Furthermore, the Infineon SiC SDT06S60 (600 V, 6A, Schottky) displayed a leakage current that was an order of magnitude higher than the rest of the devices in this group. The device tested leakage current was approximately 48 microamps at $600 \mathrm{~V}$. This is the largest leakage current in the $600 \mathrm{~V}$ group.

\section{TRANSIENT TEST RESULTS}

To test the transient behavior of the selected diodes, the devices were individually connected to the buck converter circuit shown in Figure 9. The dc source voltage and the converter resistive load were set to different values in order to accommodate the different voltage and current ratings of the tested devices. The converter switching frequency was $40 \mathrm{kHz}$. The transient current and voltage waveforms of the device under test (DUT) were captured, and the reverse recovery current of devices with similar rating were compared.

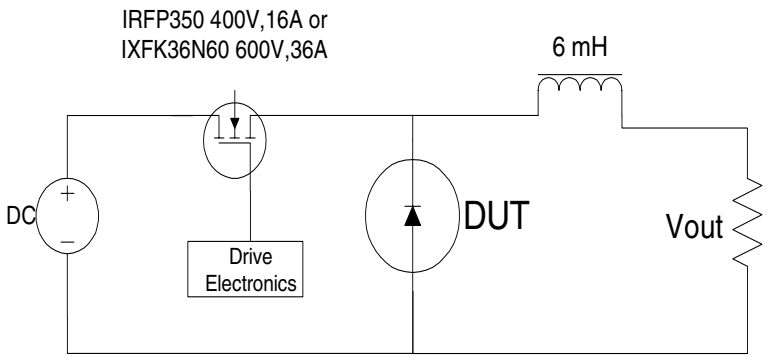

Figure 9. Buck Converter Circuit for Transient Tests

The transient tests were performed in six test groups according to the current and voltage ratings of the devices under test. Devices in each comparison group were tested as rectifiers in the buck converter circuit on Figure 9 and operated under the same switching frequency, input voltage and load conditions.

Comparison 1 was performed by operating the converter with an Input voltage of $150 \mathrm{Vdc}$ and a 50\% duty cycle to produce an average output voltage of $78.2 \mathrm{~V}$. A resistive load equal to $66.8 \mathrm{ohms}$ provided an average current of approximately 1.1 amps. These test conditions allowed the comparison of devices rated at $200 \mathrm{~V}, 1$ Amp. Table 6 shows the diodes tested in this group and the measured maximum reverse recovery current. The reverse recovery transient waveforms for these tests are included in Figure 10. 


\begin{tabular}{|l|l|c|c|c|c|}
\hline \multicolumn{1}{|c|}{ Type } & Vendor & Part \# & Voltage & Current & I pk rev \\
\hline SiC Schottky & Microsemi & UPSC200 & $200 \mathrm{~V}$ & $1 \mathrm{~A}$ & $1.26 \mathrm{~A}$ \\
Si p-n & Microsemi & UF4003 & $200 \mathrm{~V}$ & $1 \mathrm{~A}$ & $3.22 \mathrm{~A}$ \\
Si p-n & IR & 70CRU02 & $200 \mathrm{~V}$ & $35 \mathrm{~A}$ & $3.48 \mathrm{~A}$ \\
\hline
\end{tabular}

Table 6.Reverse Recovery Transient Test

Comparison \#1

Figure 10 and Table 6 clearly demonstrate the advantage of the reverse recovery behavior of a Schottky diode over the pn diode of similar ratings. The peak reverse recovery current for the Microsemi UPSC $200 \mathrm{SiC}$ Schottky is 1.26 Amps while the silicon pn diodes displayed a maximum reverse current of $3.22 \mathrm{~A}$ and $3.48 \mathrm{~A}$ respectively. This difference corresponds to significantly lower switching losses which allows the use of higher switching frequencies to obtain smaller and higher efficiency converters.

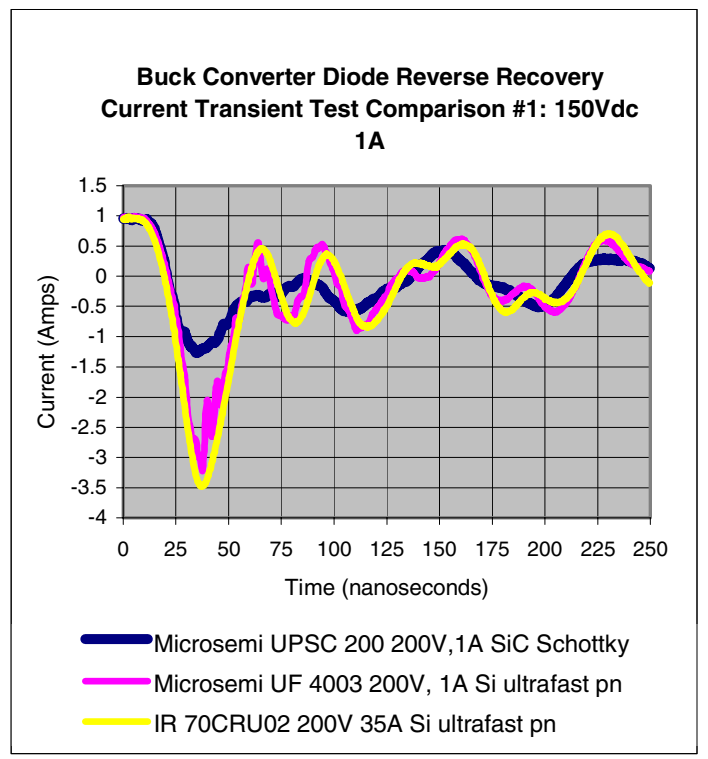

Figure 10. Buck Converter Reverse Recovery Transient Test waveforms: Comparison \#1

Comparison 2 was run with a converter input voltage of $125 \mathrm{Vdc}$, and a fixed duty cycle of $50 \%$ to provide an average output voltage of $65 \mathrm{Vdc}$. A resistive load of $60 \mathrm{ohms}$ provides a current of approximately $1.1 \mathrm{Amps}$ for this test. The objective of this comparison is to test similar ratings Schottky diodes made from different materials and test if silicon carbide provides an advantage over silicon or gallium arsenide. The voltage and current ratings in this section are not identical due to the low availability of silicon Schottky diodes rated at $200 \mathrm{~V}$ or higher. Table 7 contains the tested diodes for Comparison \#2.

\begin{tabular}{|l|l|c|c|c|c|}
\hline \multicolumn{1}{|c|}{ Type } & \multicolumn{1}{c|}{ Vendor } & Part \# & Voltage & Current & I pk rev \\
\hline SiC Schottky & Microsemi & UPSC200 & $200 \mathrm{~V}$ & $1 \mathrm{~A}$ & $1.22 \mathrm{~A}$ \\
GaAsSchottky & Motorola & MGR1018 & $180 \mathrm{~V}$ & $10 \mathrm{~A}$ & $1.39 \mathrm{~A}$ \\
Si Schottky & IR & 10CTQ150 & $150 \mathrm{~V}$ & $5 \mathrm{~A}$ & $1.83 \mathrm{~A}$ \\
\hline
\end{tabular}

Table 7. Reverse Recovery Transient Test Comparison \#2

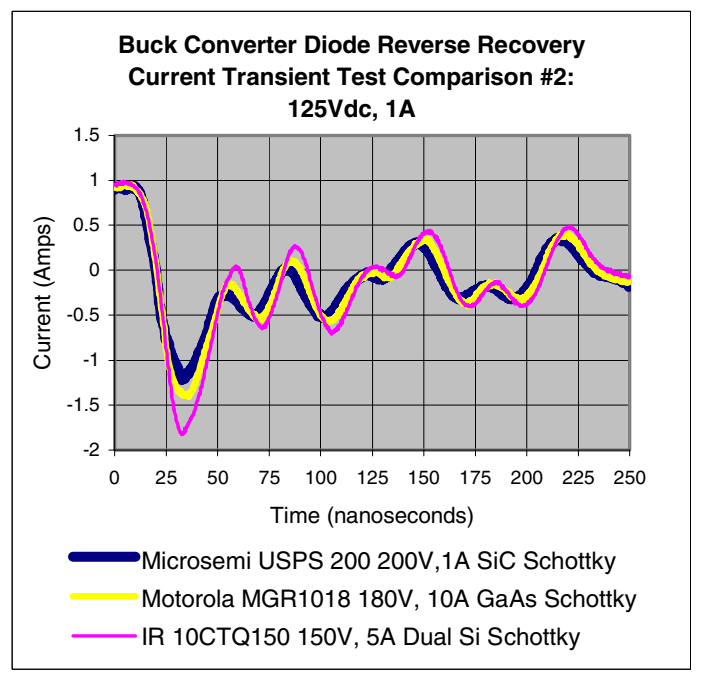

Figure 11. Buck Converter Reverse Recovery

Transient Test waveforms: Comparison \#2

Figure 11 shows the buck converter transient recovery current waveforms for the test. As expected, the difference in maximum reverse current between Schottky diodes of different materials is not as high as it is between Schottky diodes and pn diodes. The maximum reverse recovery current for the UPSC $200 \mathrm{SiC}$ Schottky is 1.22 amps while the maximum reverse current for the $\mathrm{GaAs}$ and $\mathrm{Si}$ devices was 1.39 and 1.83 Amps respectively.

\begin{tabular}{|l|l|c|c|c|c|}
\hline \multicolumn{1}{|c|}{ Type } & \multicolumn{1}{c|}{ Vendor } & Part \# & Voltage & Current & I pk rev \\
\hline SiC Schottky & Microsemi & UPSC200 & $200 \mathrm{~V}$ & $1 \mathrm{~A}$ & $0.78 \mathrm{~A}$ \\
Si Schottky & Fairchild & SB5100 & $100 \mathrm{~V}$ & $5 \mathrm{~A}$ & $0.92 \mathrm{~A}$ \\
Si Schottky & Microsemi & SR1010 & $100 \mathrm{~V}$ & $1 \mathrm{~A}$ & $1.16 \mathrm{~A}$ \\
\hline
\end{tabular}

Table 8. Reverse Recovery Transient Test

Comparison \#3

Comparison 3 results are displayed in Figure 12 and Table 8. These tests compare the UPSC $200 \mathrm{~V} \mathrm{SiC}$ Schottky with silicon Schottky diodes of lower voltage rating, specifically $100 \mathrm{~V}$, and similar current rating. This test was run with a buck converter input voltage of $75 \mathrm{Vdc}$ and a fixed duty cycle of $50 \%$ to produce an output voltage of approximately 38 volts. The selected resistive load of $40 \mathrm{ohms}$ provides an average load of approximately $0.9 \mathrm{~A}$. In this comparison group, the UPSC $200 \mathrm{~V}, 1 \mathrm{~A}$ SiC Schottky diode displayed a maximum reverse current of 0.78 A while the 
Microsemi SR1010 100 V, 1A Si Schottky showed a maximum reverse recovery current of 1.16 Amps.

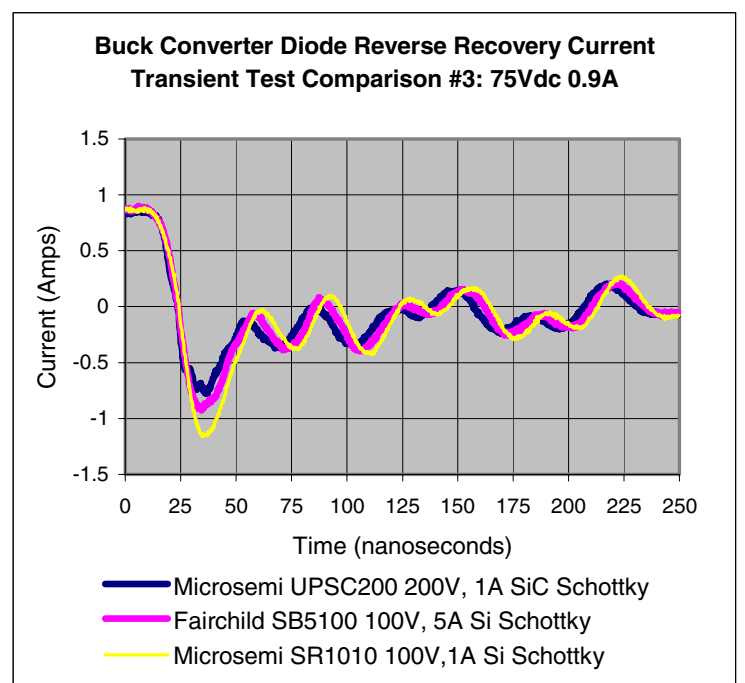

Figure 12. Buck Converter Reverse Recovery Transient Test waveforms: Comparison \#3

\begin{tabular}{|l|l|c|c|c|c|}
\hline \multicolumn{1}{|c|}{ Type } & Vendor & Part \# & Voltage & Current & I pk rev \\
\hline SiC Schottky & Infineon & SDT10S30 & $300 \mathrm{~V}$ & $10 \mathrm{~A}$ & $2.11 \mathrm{~A} \mathrm{~A}$ \\
Si pn & IXYS & DSEP 8-03A & $300 \mathrm{~V}$ & $10 \mathrm{~A}$ & $10.36 \mathrm{~A}$ \\
\hline
\end{tabular}

Table 9. Reverse Recovery Transient Test Comparison \#4

Comparison \#4 is a test of two devices of identical current and voltage rating, a SiC $300 \mathrm{~V}, 10 \mathrm{~A}$ Schottky diode by Infineon, and a $300 \mathrm{~V}, 10 \mathrm{~A} \mathrm{Si}$ pn diode by IXYS. This test was run with a buck converter input voltage of $250 \mathrm{Vdc}$ with a fixed duty cycle of $50 \%$ to obtain an output voltage of approximately $128 \mathrm{Vdc}$. The resistive load of $20 \mathrm{ohms}$ provided an average load of approximately 6.4A. Figure 13 and Table 9 contain the results of these tests. The Infineon SiC SDT10S30 Schottky showed a maximum reverse recovery current of 2.11 Amps while the IXYS DSEP 8-03A silicon ultra fast pn diode showed a maximum reverse current of 10.36 Amps. This drastic difference in transient behavior is mainly the difference between a pn diode and a Schottky diode. SiC allows the manufacture of Schottky diodes for voltages levels such as 300, 600, and $1200 \mathrm{~V}$ that are not available in Silicon. This provides to the power electronics designer the option of higher voltages Schottky power devices with superior transient recovery characteristics.

Comparison \#5 tests the transient characteristics for two 600 V, 4A devices: the Microsemi UPSC $603 \mathrm{SiC}$ Schottky, and the Microsemi 1N6628 pn ultra fast diode. For this test the buck converter input voltage was set to $400 \mathrm{Vdc}$ with a fixed duty cycle of $75 \%$
(25\% for the DUT) to obtain an average output voltage of approximately $311 \mathrm{Vdc}$. A resistive load of 297 ohms provided and average load of approximately 1.05 amps. Results for these tests are shown in Figure 14 and Table 10. The UPSC 603 SiC Schottky displayed a maximum reverse recovery current of 1.89 Amps while the 1N6628 $\mathrm{Si}$ pn showed a maximum reverse recovery current of 4.19 Amps. Once again, this compares the performance of available silicon pn junction devices at the $600 \mathrm{~V}$ level with available SiC Schottky devices with the same voltage rating. As expected, the Schottky junction shows superior reverse recovery characteristics over the pn junction.

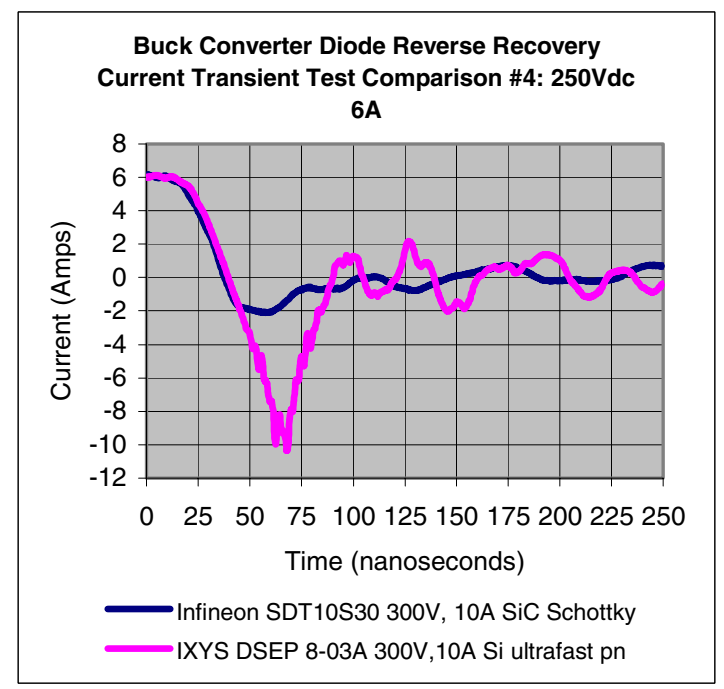

Figure 13. Buck Converter Reverse Recovery Transient Test waveforms: Comparison \#4

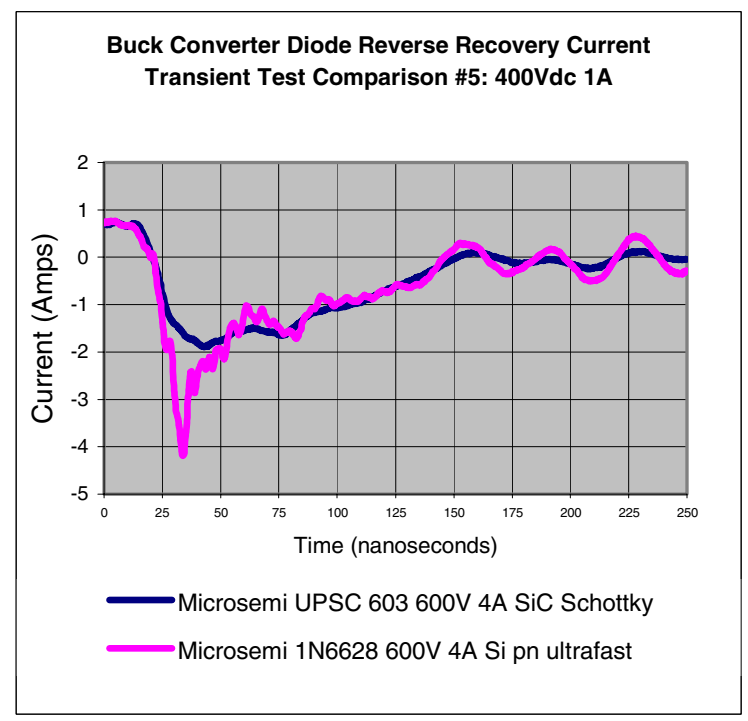

Figure 14. Buck Converter Reverse Recovery Transient Test waveforms: Comparison \#5 


\begin{tabular}{|l|c|c|c|c|c|}
\hline \multicolumn{1}{|c|}{ Type } & Vendor & Part \# & Voltage & Current & I pk rev \\
\hline SiC Schottky & Microsemi & UPSC603 & $600 \mathrm{~V}$ & $4 \mathrm{~A}$ & $1.89 \mathrm{~A}$ \\
Si pn & Microsemi & 1N6628 & $600 \mathrm{~V}$ & $4 \mathrm{~A}$ & $4.19 \mathrm{~A}$ \\
\hline
\end{tabular}

Table 10. Reverse Recovery Transient Test Comparison \#5

\begin{tabular}{|l|l|c|c|c|c|}
\hline \multicolumn{1}{|c|}{ Type } & Vendor & Part \# & Voltage & Current & I pk rev \\
\hline SiC Schottky & Infineon & SDT06S60 & $600 \mathrm{~V}$ & $6 \mathrm{~A}$ & $2.25 \mathrm{~A}$ \\
Si pn & IXYS & DSEP9-06CR & $600 \mathrm{~V}$ & $9 \mathrm{~A}$ & $3.92 \mathrm{~A}$ \\
Si pn & IR & HFA08TB60 & $600 \mathrm{~V}$ & $8 \mathrm{~A}$ & 6.92 \\
Si pn & IXYS & DESI 8-06 & $600 \mathrm{~V}$ & $8 \mathrm{~A}$ & $9.10 \mathrm{~A}$ \\
\hline
\end{tabular}

Table 11. Reverse Recovery Transient Test Comparison \#6

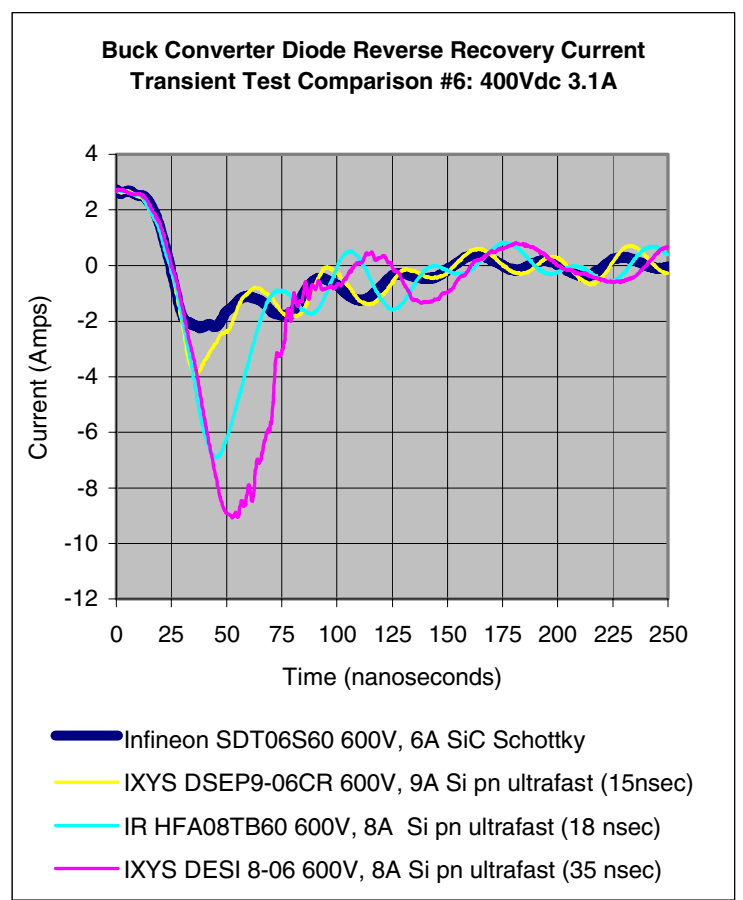

Figure 15. Buck Converter Reverse Recovery Transient Test waveforms: Comparison \#6

Comparison \#6 considers several $600 \mathrm{~V}$ devices rated at higher currents (between 6 and 10 Amps). Some of the silicon devices in this group, like the ultra fast pn IXYS DSEP9-06CR $(600 \mathrm{~V}, 9 \mathrm{~A})$ and the IR HFA08TB60 $(600 \mathrm{~V}, 8 \mathrm{~A})$, are among the fastest reverse recovery diodes available in the market for this voltage and current rating. The specified reverse recovery time (trr) for the DSEP9-06CR is 15 nanoseconds while the specified trr for the HFA08TB60 is 18 nanoseconds. The SiC Schottky used for this comparison tests was the Infineon SDT06S60, with a rating of $600 \mathrm{~V}$ and 6A. For this test the buck converter input voltage was set to $400 \mathrm{Vdc}$ with a fixed duty cycle of $75 \%$ (25\% for the DUT) to provide an output voltage of approximately
$309 \mathrm{Vdc}$. The resistive load of $98.8 \mathrm{ohms}$ provides an average load of approximately 3.1 amps. Results are shown in Figure 15 and Table 11. The SDT06S60 600 V, 6 amps SiC Schottky device has the lowest reverse recovery current of the group, with a maximum reverse current of 2.25 Amps. This device is followed in the group by the DSEP9-06CR $600 \mathrm{~V}, 9$ Amps ultra fast pn with reverse current of 3.92 Amps. It is important to remember that although this diode's transient behavior outperforms the rest of the pn junction devices in this comparison group, the DSEP906CR is also the device with the highest forward voltage drop in the steady state forward characterization tests for the $600 \mathrm{~V}$ devices. Therefore, the power electronics designer is faced with a trade off between steady state losses and switching and reverse recovery losses. The other pn devices in this comparison group, the HFA08TB60 $(600 \mathrm{~V}, 8 \mathrm{~A})$ and the DESI 8-06 $(600 \mathrm{~V}, 8 \mathrm{~A})$, displayed peak reverse currents of $6.92 \mathrm{~A}$ and $9.10 \mathrm{~A}$ respectively. Silicon Carbide clearly shows superior reverse recovery transient performance for both the $600 \mathrm{~V}$ and the $300 \mathrm{~V}$ comparison groups.

\section{$\underline{\text { CONCLUSIONS }}$}

The results of the steady state characterization tests of the commercially available SiC Schottky diodes show that current state of the art silicon ultra fast pn diodes outperform the new breed of SiC high voltage Schottky devices. This is evident in the higher forward voltage drops measured in the $\mathrm{SiC}$ devices at the devices rated current, and also in the higher reverse leakage currents measured at the devices rated voltage. This implies that these devices are not suited for low power, low output voltage applications where efficiency is the main design driver. In addition, there are reliability concerns related to $\mathrm{SiC}$ Schottky diodes limited capability to withstand avalanche currents. However, $\mathrm{SiC}$ has made possible the fabrication of new high voltage 300,600 , and $1200 \mathrm{~V}$ Schottky diodes that are not available in Silicon. The Schottky devices advantage over pn junction devices lies in their superior reverse recovery transient behavior. These devices substantially reduce the maximum reverse recovery current measured in power electronics switching applications such as the buck dc to dc converter tested a NASA Glenn Research Center. This superior transient behavior results in significant reductions in switching losses at high frequencies. The higher frequency operation has the potential for higher power density power electronics packaging. Furthermore, the advantages of $\mathrm{SiC}$ devices with respect to extreme high temperature operation and 
radiation tolerance are benefits that directly address NASA's needs for deep space power management and distribution systems.

The devices tested are the first generation of this new breed of commercial $\mathrm{SiC}$ devices. It is reasonable to expect that the devices performance will continue to improve as $\mathrm{SiC}$ fabrication and processing techniques continue to develop, advance, and mature. However, care must be taken before specifying these devices for actual applications because their steady state performance, at the present time, is not yet superior to available silicon devices.

\section{REFERENCES}

[1] K. Shenai, R. Scott, and B.J. Baliga, "Optimum Materials for High Power Electronics," IEEE Transactions on Electron Devices, vol. 36, no.9, pp.1811-1823, 1989.

[2] J. Millman, A. Grabel, Microelectronics. Second Edition. McGraw-Hill Book Company, 1987.

[3] K. Walters, B. Werner, "Introduction to Schottky Rectifiers," Microsemi Application Notes, Micro Notes Series 401.

[4] C. Miesner, R. Rupp, H. Kapels, M. Krach, I. Zverev, "ThinQ! Silicon Carbide Schottky Diodes: An SMPS Circuit Designer's Dream Comes True!" Infineon Technologies Application Notes Technical White Paper.

[5] K. Shenai, P.G. Neudeck, "Defect Engineering and Reliability Study of SiC High Power Devices," Space Solar Power Exploratory Research and Technology Program Report. November 2000. 
Public reporting burden for this collection of information is estimated to average 1 hour per response, including the time for reviewing instructions, searching existing data sources, gathering and maintaining the data needed, and completing and reviewing the collection of information. Send comments regarding this burden estimate or any other aspect of this collection of information, including suggestions for reducing this burden, to Washington Headquarters Services, Directorate for Information Operations and Reports, 1215 Jefferson Davis Highway, Suite 1204, Arlington, VA 22202-4302, and to the Office of Management and Budget, Paperwork Reduction Project (0704-0188), Washington, DC 20503.

\begin{tabular}{|l|l|l}
\hline 1. AGENCY USE ONLY (Leave blank) & $\begin{array}{c}\text { 2. REPORT DATE } \\
\text { August } 2003\end{array}$ & $\begin{array}{r}\text { 3. REPORT TYPE AND DATES COVERED } \\
\text { Technical Memorandum }\end{array}$ \\
\hline
\end{tabular}

\section{TITLE AND SUBTITLE}

Silicon Carbide Diodes Performance Characterization and Comparison With Silicon Devices

\section{AUTHOR(S)}

Ramon C. Lebron-Velilla, Gene E. Schwarze, and Scott Trapp

\section{FUNDING NUMBERS}

WBS-22-755-60-15

\section{PERFORMING ORGANIZATION NAME(S) AND ADDRESS(ES)}

National Aeronautics and Space Administration

John H. Glenn Research Center at Lewis Field

Cleveland, Ohio 44135-3191
8. PERFORMING ORGANIZATION REPORT NUMBER

E-14071

\section{SPONSORING/MONITORING AGENCY NAME(S) AND ADDRESS(ES)}

National Aeronautics and Space Administration

Washington, DC 20546-0001
10. SPONSORING/MONITORING AGENCY REPORT NUMBER

NASA TM-2003-212511

\section{SUPPLEMENTARY NOTES}

Prepared for the First International Energy Conversion Engineering Conference cosponsored by the American Institute of Aeronautics and Astronautics (AIAA), the American Society of Mechanical Engineers (ASME), and the Institute of Electrical and Electronics (IEEE), Portsmouth, Virginia, August 17-21, 2003. Ramon C. Lebron-Velilla and Gene E. Schwarze, NASA Glenn Research Center; and Scott Trapp, University of Toledo, Toledo, Ohio 43606. Responsible person, Ramon C. Lebron-Velilla, organization code 5450, 216-433-6482.

12a. DISTRIBUTION/AVAILABILITY STATEMENT

\section{2b. DISTRIBUTION CODE}

Unclassified - Unlimited

Subject Categories: 33, 20, and 76

Distribution: Nonstandard

Available electronically at http://gltrs.grc.nasa.gov

This publication is available from the NASA Center for AeroSpace Information, 301-621-0390.

\section{ABSTRACT (Maximum 200 words)}

Commercially available silicon carbide $(\mathrm{SiC})$ Schottky diodes from different manufacturers were electrically tested and characterized at room temperature. Performed electrical tests include steady state forward and reverse I-V curves, as well as switching transient tests performed with the diodes operating in a hard switch dc-to-dc "buck" converter. The same tests were performed in current state of the art silicon $(\mathrm{Si})$ and gallium arsenide (GaAs) Schottky and pn junction devices for evaluation and comparison purposes. The SiC devices tested have a voltage rating of 200, 300, and $600 \mathrm{~V}$. The comparison parameters are forward voltage drop at rated current, reverse current at rated voltage and peak reverse recovery currents in the dc to dc converter. Test results show that steady state characteristics of the tested SiC devices are not superior to the best available Si Schottky and ultra fast pn junction devices. Transient tests reveal that the tested $\mathrm{SiC}$ Schottky devices exhibit superior transient behavior. This is more evident at the 300 and $600 \mathrm{~V}$ rating where $\mathrm{SiC}$ Schottky devices showed drastically lower reverse recovery currents than Si ultra fast pn diodes of similar rating.

\begin{tabular}{|c|c|c|}
\hline \multicolumn{3}{|c|}{$\begin{array}{l}\text { 14. SUBJECT TERMS } \\
\text { Silicon carbide diodes; SiC diodes application to dc-to-dc converters; Silicon carbide } \\
\text { Schottky diodes tests }\end{array}$} \\
\hline $\begin{array}{l}\text { 17. SECURITY CLASSIFICATION } \\
\text { OF REPORT } \\
\text { Unclassified }\end{array}$ & $\begin{array}{l}\text { 18. SECURITY CLASSIFICATION } \\
\text { OF THIS PAGE } \\
\text { Unclassified }\end{array}$ & $\begin{array}{l}\text { 19. SECURITY CLASSIFICATION } \\
\text { OF ABSTRACT } \\
\text { Unclassified }\end{array}$ \\
\hline Unclassified & Unclassified & Unclassified \\
\hline
\end{tabular}

